Article

\title{
Dynamic Ochratoxin A Production by Strains of Aspergillus niger Intended Used in Food Industry of China
}

\author{
Xiaomin Han ${ }^{1,+}$, Hongru Jiang ${ }^{2,+}$ and Fengqin $\mathrm{Li}^{1, *(\mathbb{D})}$ \\ 1 NHC Key Laboratory of Food Safety Risk Assessment, China National Center for Food Safety Risk \\ Assessment, Beijing 100021, China; hanxiaomin@cfsa.net.cn \\ 2 National Institute for Nutrition and Health, Chinese Center for Disease Control and Prevention, \\ Beijing 10050, China; jianghr@ninh.chinacdc.cn \\ * Correspondence: lifengqin@cfsa.net.cn; Tel./Fax: +86-10-6777-6356 \\ + These authors contributed equally to this work.
}

Received: 8 January 2019; Accepted: 14 February 2019; Published: 18 February 2019

\begin{abstract}
Thirty strains of Aspergillus niger, including 27 intended used in the food industry of China, were studied for their ochratoxin A (OTA) production on the three natural substrates-corn, rice, and wheat bran-at different time intervals by high-performance liquid chromatography. It was found that the frequencies of OTA for the studied 27 industrial strains ranged from $14.8 \%(4 / 27)$ at day 28 to $25.9 \%(7 / 27)$ at day 7 on corn, $14.8 \%(4 / 27)$ at day 7 to $33.3 \%(9 / 27)$ at day 21 on rice, and $22.2 \%(6 / 27)$ at day 7,14 , and 28 to $44.4 \%(12 / 27)$ at day 21 on wheat bran, respectively. The average concentrations of OTA produced by the studied 27 industrial strains ranged from $5.1 \mu \mathrm{g} / \mathrm{kg}$ at day 28 to $8.7 \mu \mathrm{g} / \mathrm{kg}$ at day 21 on corn, $4.2 \mu \mathrm{g} / \mathrm{kg}$ at day 7 to $17.9 \mu \mathrm{g} / \mathrm{kg}$ at day 14 on rice, and $4.5 \mu \mathrm{g} / \mathrm{kg}$ at day 7 to $7.2 \mu \mathrm{g} / \mathrm{kg}$ at day 21 on wheat bran, respectively. Furthermore, the OTA production in the studied 27 industrial strains of A.niger was strongly associated with their function (or application), culture substrate, and time. The saccharifying enzyme producers produced higher levels of OTA, compared with the organic acid producers, the tannase producers, and the $\beta$-galactosidase producer, while concentration differences were also observed in OTA production among strains of A.niger with the same application. In a word, some strains of A.niger intended used in the Chinese food industry indeed have the capability of producing OTA, elevating the risks to food safety associated with their use.
\end{abstract}

Keywords: Aspergillus niger; Ochratoxin A; Food industry; China

Key Contribution: Strains of A.niger intended used in the food industry of China are firstly reported that they can produce OTA on the studied natural substrates.

\section{Introduction}

Ochratoxin A (OTA) was originally described as a metabolite of Aspergillus ochraceus by Wilhem in 1965, and the following studies indicated that many kinds of fungal species, including Penicillium such as P.expansum, P.verrucosum, and P.chrysogenum, as well as Aspergillus such as A.niger, A.melleus, and A.albertensis, were able to produce ochratoxins [1,2]. OTA possesses nephrotoxic, immunosuppressive, teratogenic, and carcinogenic properties, and was listed as a Group 2B carcinogen by the International Agency for Research on Cancer (IRAC) in 1993 [3,4].

Aspergillus niger, as one of the most important industrial filamentous fungal species, is employed in biotechnology and is also one of the most common natural contamination fungi in food and feed [5-7]. Although it was regarded as Generally Regarded As Safe (GRAS) by the U.S. Food and 
Drug Administration (FDA) in 1987, several reports revealed that strains of A.niger isolated from several substrates such as raisins, grapes, maize, mixed feeds and component raw materials, and Colombian coffee beans could produce OTA [6-10]. However, only a few reports were about the production of OTA in strains of A.niger used in the food industry [11-13], and there were no reports about the OTA production for strains of A.niger used in the food industry of China. Therefore, our aim is to establish the OTA temporal producing profile on different natural substrates for strains of A.niger intended for use in the food industry of China in this study.

\section{Results}

\subsection{OTA Temporal Producing Profile for Strains of A.niger Used in This Study}

Thirty strains of A.niger were used to survey their dynamic OTA producing profiles (Table 1). Firstly, it should be noted that the culture conditions of OTA production for the strains of A.niger used in this study were the same as those of the fumonisin (FB) production which we reported previously [14]. It was found that the positive rates of OTA produced by the studied 30 strains ranged from $13.3 \%$ at day 28 to $26.7 \%$ at day 7 and day 21 on corn, $13.3 \%$ at day 7 to $30.0 \%$ at day 21 on rice, and $20.0 \%$ at day 14 and day 28 to $40.0 \%$ at day 21 on wheat bran, while the average concentrations of OTA for those strains ranged from $4.6 \mu \mathrm{g} / \mathrm{kg}$ at day 28 to $7.8 \mu \mathrm{g} / \mathrm{kg}$ at day $21 \mathrm{on}$ corn, $3.8 \mu \mathrm{g} / \mathrm{kg}$ at day 7 to $16.2 \mu \mathrm{g} / \mathrm{kg}$ at day 14 on rice, and $4.1 \mu \mathrm{g} / \mathrm{kg}$ at day 7 to $6.5 \mu \mathrm{g} / \mathrm{kg}$ at day 21 on wheat bran, respectively. Therefore, the concentrations of OTA at different time intervals were far lower than those detected for $\mathrm{FB}_{2}$ under the same culture conditions [14]. The maximum levels of OTA for the studied 30 strains of A.niger at all time intervals were $181.5 \mu \mathrm{g} / \mathrm{kg}$ for corn, $427.8 \mu \mathrm{g} / \mathrm{kg}$ for rice, and $175.4 \mu \mathrm{g} / \mathrm{kg}$ for wheat bran, while the maximum levels of $\mathrm{FB}_{2}$ for those strains under the same culture conditions were $70,488 \mu \mathrm{g} / \mathrm{kg}$ for corn, $54,284 \mu \mathrm{g} / \mathrm{kg}$ for rice, and $38,094 \mu \mathrm{g} / \mathrm{kg}$ for wheat bran [14]. The positive rates and the concentration levels of OTA for the saccharifying enzyme producers were higher than those produced by the organic acid producers, the tannase producers, and the $\beta$-galactosidase producer, a result which corresponded with that of our previous report for $\mathrm{FB}_{2}$ production [14]. As with the $\mathrm{FB}_{2}$ production in those strains, concentration differences were also observed in OTA production among the strains with the same function. For example, the saccharifying enzyme producers coding SN-01 and SN-11 yielded OTAs at higher levels at all time intervals for corn (SN-01) and wheat bran (SN-11), with a minimum level of $90.3 \mu \mathrm{g} / \mathrm{kg}$ for SN-01 on corn and $75.9 \mu \mathrm{g} / \mathrm{kg}$ for SN-11 on wheat bran, compared to those yielded by the saccharifying enzyme producers coding $\mathrm{SN}-03, \mathrm{SN}-08, \mathrm{SN}-09$, and $\mathrm{SN}-12$ under the same culture conditions, in which no OTA was detected on any of the three studied substrates, with the exception of SN-08 on wheat bran at day 21 and $\mathrm{SN}-12$ on rice at day 14. Seven tannase producers and six organic acid producers only yielded OTA on one or two substrates at all time intervals (maximum $<15.0 \mu \mathrm{g} / \mathrm{kg}$ ), except for one tannase producer coding TA-07 at day 14 (concentration $=427.8 \mu \mathrm{g} / \mathrm{kg}$ ), day 21 (concentration $=176.5 \mu \mathrm{g} / \mathrm{kg}$ ), and day 28 (concentration $=190.2 \mu \mathrm{g} / \mathrm{kg}$ ) on rice. For the $\beta$-galactosidase producer GA-01, it was negative for OTA on corn and wheat bran at all time intervals, but it was positive for OTA at low levels (maximum $<20 \mu \mathrm{g} / \mathrm{kg}$ ) on rice at all time intervals. Strains of ACCC 30557 and ATCC 16404 did not produce OTA on any of the three natural substrates, with the exception of ACCC 30557 on wheat bran at day 7 (concentration $=0.6 \mu \mathrm{g} / \mathrm{kg}$ ) and ATCC 16404 on corn at day 7 (concentration $=0.2 \mu \mathrm{g} / \mathrm{kg}$ ) and day 21 (concentration $=0.3 \mu \mathrm{g} / \mathrm{kg}$ ). One strain of A.niger isolated from corn in our lab that coding SI- 01 was negative for OTA on all three studied substrates at all time intervals, with the exception of corn at day 21 (concentration $=0.3 \mu \mathrm{g} / \mathrm{kg}$ ). 
Table 1. Concentrations of ochratoxin A (OTA) for the strains of A.niger used in this study at different time intervals.

\begin{tabular}{|c|c|c|c|c|c|c|c|c|c|c|c|c|}
\hline \multirow{2}{*}{ Stain No ${ }^{1}$} & \multicolumn{4}{|c|}{ Corn $(\mu \mathrm{g} / \mathrm{kg})$} & \multicolumn{4}{|c|}{ Rice $(\mu \mathrm{g} / \mathrm{kg})$} & \multicolumn{4}{|c|}{ Wheat Bran $(\mu \mathrm{g} / \mathrm{kg})$} \\
\hline & Day 7 & Day 14 & Day 21 & Day 28 & Day 7 & Day 14 & Day 21 & Day 28 & Day 7 & Day 14 & Day 21 & Day 28 \\
\hline SN-01 & 128.0 & 117.4 & 181.5 & 90.3 & nd & nd & nd & nd & nd & nd & 0.1 & nd \\
\hline $\mathrm{SN}-02$ & 1.3 & 0.3 & nd & nd & 0.8 & 0.4 & 0.2 & 0.2 & 2.0 & nd & 0.4 & 3.4 \\
\hline SN-03 & nd $^{2}$ & nd & nd & nd & nd & nd & nd & nd & nd & nd & nd & nd \\
\hline SN-04 & 3.5 & 0.4 & 0.1 & nd & 0.1 & nd & nd & nd & 35.0 & 0.5 & 0.3 & 0.6 \\
\hline SN-05 & 4.7 & 21.8 & 52.0 & 46.2 & 88.0 & 29.0 & 22.3 & 14.8 & nd & nd & nd & nd \\
\hline SN-06 & nd & nd & 0.2 & nd & 25.0 & 26.0 & 9.8 & 8.0 & nd & nd & nd & nd \\
\hline SN-07 & nd & nd & nd & nd & nd & nd & 0.2 & nd & 5.0 & nd & 0.5 & nd \\
\hline SN-08 & nd & nd & nd & nd & nd & nd & nd & nd & nd & nd & 0.3 & nd \\
\hline SN-09 & nd & nd & nd & nd & nd & nd & nd & nd & nd & nd & nd & nd \\
\hline SN-10 & 2.0 & nd & nd & nd & nd & nd & nd & nd & nd & nd & nd & nd \\
\hline SN-11 & 0.2 & 4.1 & nd & nd & nd & 0.7 & 0.9 & 0.2 & 75.9 & 116.2 & 175.4 & 95.3 \\
\hline SN-12 & nd & nd & nd & nd & nd & 0.5 & nd & nd & nd & nd & nd & nd \\
\hline SN-13 & nd & nd & nd & nd & nd & nd & nd & nd & nd & 40.1 & 0.5 & 10.4 \\
\hline OA-01 & nd & nd & nd & 0.7 & nd & nd & 0.2 & nd & nd & nd & 13.2 & nd \\
\hline OA-02 & nd & nd & nd & nd & nd & nd & nd & nd & nd & 0.9 & 1.5 & nd \\
\hline OA-03 & nd & nd & nd & nd & nd & nd & nd & nd & nd & nd & nd & nd \\
\hline OA-04 & nd & nd & nd & nd & nd & nd & nd & nd & nd & nd & nd & nd \\
\hline OA-05 & nd & nd & nd & 0.5 & nd & nd & 0.8 & 0.2 & nd & nd & nd & nd \\
\hline OA-06 & 0.4 & 0.4 & 0.3 & nd & nd & nd & nd & nd & nd & nd & nd & nd \\
\hline TA-01 & nd & nd & nd & nd & nd & nd & nd & nd & nd & nd & nd & nd \\
\hline TA-02 & nd & nd & nd & nd & nd & nd & nd & nd & nd & nd & nd & nd \\
\hline TA-03 & nd & nd & nd & nd & nd & nd & nd & nd & nd & nd & nd & nd \\
\hline TA-04 & nd & nd & nd & nd & nd & nd & nd & nd & 1.9 & 1.9 & 1.0 & 11.7 \\
\hline TA-05 & nd & nd & nd & nd & nd & 0.2 & nd & nd & nd & nd & nd & nd \\
\hline TA-06 & nd & nd & nd & nd & nd & nd & nd & nd & nd & nd & 0.4 & nd \\
\hline TA-07 & nd & nd & 0.6 & nd & nd & 427.8 & 176.5 & 190.2 & 3.0 & 0.3 & 0.5 & 5.1 \\
\hline GA-01 & nd & nd & nd & nd & nd & nd & 0.2 & 15.9 & nd & nd & nd & nd \\
\hline ACCC 30557 & nd & nd & nd & nd & nd & nd & nd & nd & 0.6 & nd & nd & nd \\
\hline ATCC 16404 & 0.2 & nd & 0.3 & nd & nd & nd & nd & nd & nd & nd & nd & nd \\
\hline SI-01 & nd & nd & 0.3 & nd & nd & nd & nd & nd & nd & nd & nd & nd \\
\hline
\end{tabular}

${ }^{1}$ SN 01 to SN-13: saccharifying enzyme producer $(n=13)$; OA-01 to OA-06: organic acid producer $(n=6)$; TA-01 to TA-07: tannase producer $(n=7)$; GA-01: $\beta$-galactosidase producer $(n=1)$; SI-0: isolated from corn $(n=1) .{ }^{2}$ nd: not detected or lower than the limit of detection $(<$ LOD). 


\subsection{Substrates Effect on OTA Production Profile by A.niger Intended Used in Food Industry}

The OTA production profile for strains of $A$. niger with different functions on different substrates was presented in Table 2. First, it was found that the OTA production in 27 strains of A.niger varied by substrates for SN-01 ( $p<0.01)$, SN-06 $(p<0.01)$, SN-11 $(p<0.01)$, OA-06 $(p<0.01)$, and TA-07 $((p<0.05)$. For the studied saccharifying enzyme producers, on corn, their average levels of OTA increased steadily and reached a maximum of $68.3 \mu \mathrm{g} / \mathrm{kg}$ at day 28 , whereas on rice, their average concentrations of OTA decreased over time with a maximum of $28.5 \mu \mathrm{g} / \mathrm{kg}$ at day 7 and a minimum of $5.8 \mu \mathrm{g} / \mathrm{kg}$ at day 28; however, on wheat bran, the average concentration of OTA increased until day 14 after inoculation with a maximum of $52.3 \mu \mathrm{g} / \mathrm{kg}$; then, it decreased to an average of $25.4 \mu \mathrm{g} / \mathrm{kg}$ at day 21 and increased again to an average concentration of $27.4 \mu \mathrm{g} / \mathrm{kg}$ at day 28 . Hence, high average concentrations of OTA on corn and wheat bran were observed in comparison with those on rice except on day 7 for thirteen saccharifying enzyme producers. Regarding the six organic acid producers, at least one strain was positive for OTA in corn at all time intervals, but no OTA was detected on rice on day 7 and day 14 and on wheat bran on day 7 and day 28. On the other hand, for the seven tannase producers, at least two strains yielded OTA on wheat bran at all time intervals, and only one strain was positive for OTA on day 21 on corn, and only one or two strains were positive for OTA at day 14, 21 , and 28 on rice, respectively. For instance, one tannase producer coding TA-07 produced high levels of OTA on rice on day 14, 21, and 28 (concentration $=427.8 \mu \mathrm{g} / \mathrm{kg}, 176.5 \mu \mathrm{g} / \mathrm{kg}$, and $190.2 \mu \mathrm{g} / \mathrm{kg}$ ), but yielded low levels of OTA (or none) on corn and wheat bran. For one $\beta$-galactosidase producer, only $0.2 \mu \mathrm{g} / \mathrm{kg}$ and $15.9 \mu \mathrm{g} / \mathrm{kg}$ of OTA were detected on rice on day 21 and day 28, respectively. Furthermore, lower positive rates and average concentrations of OTA for the strains of A.niger with the same function on the studied three substrates were observed than those detected for $\mathrm{FB}_{2}$ [14]. For instance, $100 \%$ of the saccharifying enzyme producers produced $\mathrm{FB}_{2}$ on all three studied natural substrates at all time intervals, while only $40 \%$ or less yielded OTA on the studied three substrates at all time intervals except for those strains on day 7 on corn (positive $=46 \%$ ) and at day 21 on wheat bran (positive $=54 \%$ ). In addition, only one or two organic acid producers were positive for OTA on the studied three substrates, with lower than average concentrations of OTA (maximum $=7.4 \mu \mathrm{g} / \mathrm{kg}$ ), which was also far lower than those for $\mathrm{FB}_{2}$ [14]. This observation pointed to the important effect of the components of the substrates on OTA production for A.niger and its intended uses in the Chinese food industry, and it could be concluded that higher levels of OTA were usually produced on wheat bran and corn than those detected on rice under the same culture conditions.

Table 2. Substrates effect on the frequencies and the mean concentrations of OTA produced by 27 strains of A.niger used as different applications.

\begin{tabular}{|c|c|c|c|c|c|c|c|}
\hline \multirow{3}{*}{ Substrate } & \multirow{3}{*}{$\begin{array}{c}\text { Time } \\
\text { Intervals } \\
\text { (Day) }\end{array}$} & \multicolumn{6}{|c|}{ OTA Production for Different Functions of A.niger } \\
\hline & & \multicolumn{2}{|c|}{$\begin{array}{l}\text { Saccharifying Enzyme } \\
\text { Producer }(n=13)\end{array}$} & \multicolumn{2}{|c|}{$\begin{array}{l}\text { Organic Acid Producer } \\
\qquad(n=6)\end{array}$} & \multicolumn{2}{|c|}{$\begin{array}{c}\text { Tannase Producer } \\
(n=7)\end{array}$} \\
\hline & & $\begin{array}{c}\text { No. of } \\
\text { Positive (\%) }\end{array}$ & $\begin{array}{l}\text { Mean (Range) } \\
(\mu \mathrm{g} / \mathrm{kg})\end{array}$ & $\begin{array}{c}\text { No. of } \\
\text { Positive }(\%)\end{array}$ & $\begin{array}{c}\text { Mean (Range) } \\
(\mu \mathrm{g} / \mathrm{kg})\end{array}$ & $\begin{array}{c}\text { No. of } \\
\text { Positive (\%) }\end{array}$ & $\begin{array}{l}\text { Mean (Range) } \\
(\mu \mathrm{g} / \mathrm{kg})\end{array}$ \\
\hline \multirow{4}{*}{ Corn } & 7 & $6(46)$ & $23.3(0.2-128.0)$ & $1(17)$ & 0.4 & 0 & 0 \\
\hline & 14 & $5(38)$ & $28.8(0.3-117.4)$ & $1(17)$ & 0.4 & 0 & 0 \\
\hline & 21 & $4(31)$ & $58.5(0.1-181.5)$ & $1(17)$ & 0.3 & $1(14)$ & 0.6 \\
\hline & 28 & $2(15)$ & $68.3(46.2-90.3)$ & $2(33)$ & $0.6(0.5-0.7)$ & 0 & 0 \\
\hline \multirow{4}{*}{ Rice } & 7 & $4(31)$ & $28.5(0.1-88.0)$ & 0 & 0 & 0 & 0 \\
\hline & 14 & $5(38)$ & $11.3(0.4-29.0)$ & 0 & 0 & $2(29)$ & $214.0(0.2-427.8)$ \\
\hline & 21 & $5(38)$ & $6.7(0.2-22.3)$ & $2(33)$ & $0.5(0.2-0.8)$ & $1(14)$ & 176.5 \\
\hline & 28 & $4(31)$ & $5.8(0.2-14.8)$ & $1(17)$ & 0.2 & $1(14)$ & 190.2 \\
\hline \multirow{4}{*}{$\begin{array}{l}\text { Wheat } \\
\text { bran }\end{array}$} & 7 & $4(31)$ & $29.5(2.0-75.9)$ & 0 & 0 & $2(29)$ & $2.5(1.9-3.0)$ \\
\hline & 14 & $3(23)$ & $52.3(0.5-116.2)$ & $1(17)$ & 0.9 & $2(29)$ & $1.1(0.3-1.9)$ \\
\hline & 21 & $7(54)$ & $25.4(0.1-175.4)$ & $2(33)$ & $7.4(1.5-13.2)$ & $3(43)$ & $0.6(0.4-1.0)$ \\
\hline & 28 & $4(31)$ & $27.4(0.6-95.3)$ & 0 & 0 & $2(29)$ & $8.4(5.1-11.7)$ \\
\hline
\end{tabular}




\subsection{Average Concentration Distribution of OTA Produced by 27 Strains of A.niger Intended Used in Chinese Food Industry}

The average concentration distribution of OTA produced by 27 strains of A.niger at all time intervals on the three natural substrates is given in Figure 1. According to the national food safety standard, Maximum Levels of Mycotoxins in Foods GB2761-2017 in China, the maximum levels of OTA in grape wine, coffee beans and coffee powder, and instant coffee were $2.0 \mu \mathrm{g} / \mathrm{kg}, 5.0 \mu \mathrm{g} / \mathrm{kg}$, and $10.0 \mu \mathrm{g} / \mathrm{kg}$, respectively. Therefore, the 27 strains tested were separated into four groups, and they were $\leq 2.0 \mu \mathrm{g} / \mathrm{kg}, 2.0-5.0 \mu \mathrm{g} / \mathrm{kg}, 5.1-10.0 \mu \mathrm{g} / \mathrm{kg}$, and $>10.0 \mu \mathrm{g} / \mathrm{kg}$ based on their OTA average levels at all time intervals on different substrates. Two $(2 / 27,7 \%)$ strains on corn, one $(1 / 27,4 \%)$ strain on rice, and three $(3 / 27,11 \%)$ strains on wheat bran produced OTA at an average concentration higher than $10.0 \mu \mathrm{g} / \mathrm{kg}$, with a maximum of $129.3 \mu \mathrm{g} / \mathrm{kg}$ on corn, $264.8 \mu \mathrm{g} / \mathrm{kg}$ on rice, and $115.7 \mu \mathrm{g} / \mathrm{kg}$ on wheat bran, respectively, while there was one $(1 / 27,4 \%)$ strain producing OTA at an average concentration between $5.1 \mu \mathrm{g} / \mathrm{kg}$ and $10.0 \mu \mathrm{g} / \mathrm{kg}$ on rice and wheat bran, but none on corn. Only one $(1 / 27,4 \%)$, zero $(0 / 27,0 \%)$, and three $(3 / 27,11 \%)$ strains yielded the average levels of OTA, ranging from $2.0 \mu \mathrm{g} / \mathrm{kg}$ to $5.0 \mu \mathrm{g} / \mathrm{kg}$ on corn, rice, and wheat bran, respectively. Almost all strains, including $24(89 \%)$ on corn, $25(93 \%)$ on rice, and $20(74 \%)$ on wheat bran, synthesized OTA at average levels below or equal to $2.0 \mu \mathrm{g} / \mathrm{kg}$ on the three natural substrates. Therefore, the highest yield of OTA was produced on wheat bran and corn, followed by that on rice, in a trend similar to that for $\mathrm{FB}_{2}$ production, as reported earlier [14].

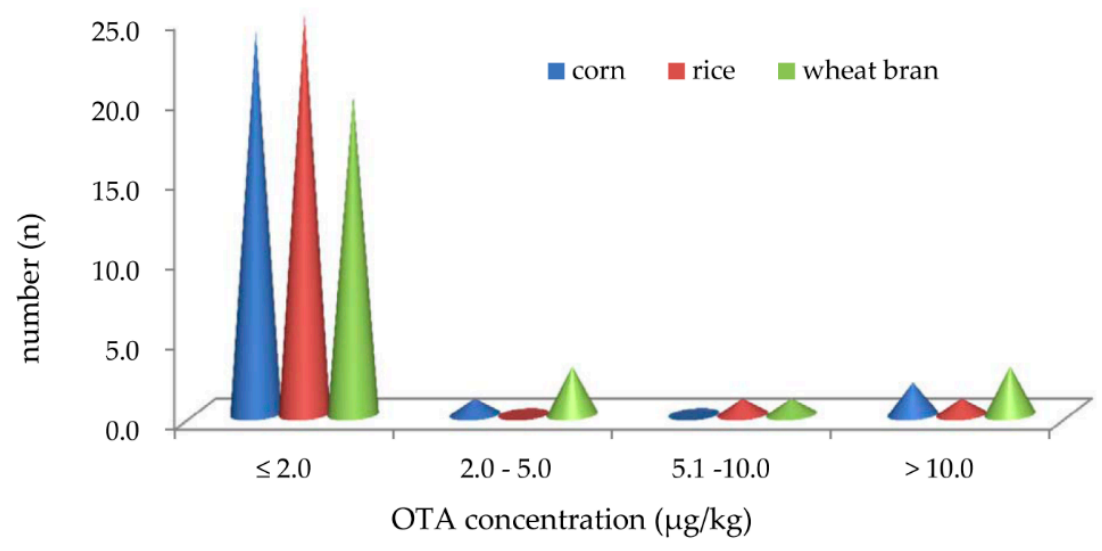

Figure 1. OTA average concentration distribution produced by 27 strains of a.niger with intended uses in the Chinese food industry. $n=$ OTA positive strain number.

\section{Discussion}

In food and feed applications, strains of A. niger-representing the workhorses of the industrial biotechnology — have a long and extensively documented history of safe use [13]. Approximately $1-41 \%$ strains of A.niger isolated from foods such as dried vine fruits and wine grapes were capable of producing OTA depending on their commodity and their culture conditions $[9-11,15,16]$. Frisvad et al. reported that among the industrial strains of A.niger $(n=69)$, about $33 \%$ of them could produce OTA, including the three important industrial strains NRRL 337, NRRL 3112, and NRRL 3122 [11]. To the best of our knowledge, this is the first report on the OTA production by strains of A.niger with intended uses in the Chinese food industry. The positive rates of OTA for 27 strains of A.niger used in our study ranged from $14.8 \%(4 / 27)$ on corn and rice to $44.4 \%(12 / 27)$ on wheat bran, which included the OTA frequency for the industrial strains of $A$. niger (positive rate $=33 \%$ ), but higher than those for the nonindustrial strains of A.niger (positive rate $=7 \%$ ) reported by Frisvad et al. [11]. All these differences may result from the genetic variations (containing or not containing the toxin-producing genes) or from the culture condition differences, especially the culture temperature, the time, and the medium [9-11,15-17]. 
Interestingly, the positive rates and the concentrations of OTA produced by strains of A.niger used in this study were highly related to their application. Generally, strains used for saccharifying enzyme production yielded higher levels of OTA than those used for the organic acid production and the tannase production under the same culture conditions. In addition, strains of A.niger with the same function yielded different amounts of OTA under the same culture conditions. Among the thirteen saccharifying enzyme producers, strains coding SN-01 and SN-011 were high OTA producers, while strains coding $\mathrm{SN}-03, \mathrm{SN}-08, \mathrm{SN}-09$, and $\mathrm{SN}-12$ were low OTA producers or nonproducers. In order to clarify these differences, it was necessary to simultaneously detect their OTA concentrations and their related products, such as enzymes and organic acid [18-23], as well as the related genes and their expressions which participated in OTA biosynthesis [11,12].

Last, the positive rates and the average concentrations of OTA in the studied strains of A.niger were very low compared with the positive rates and the average concentrations of $\mathrm{FB}_{2}$ produced by strains of A.niger under the same conditions, which we have reported previously. All the concentrations of OTA were in the levels of $\mu \mathrm{g} / \mathrm{kg}$ (maximum $=427.8 \mu \mathrm{g} / \mathrm{kg}$ ), while most of the concentrations of $\mathrm{FB}_{2}$ were in the levels of $\mathrm{mg} / \mathrm{kg}$ (maximum $=70,488 \mu \mathrm{g} / \mathrm{kg}$ ) [14]. Because the culture conditions for $\mathrm{FB}_{2}$ production and OTA production were exactly same, the only differences were the different toxin detection methods. It was inferred that there was no correlation between the $\mathrm{FB}_{2}$ production and the OTA production, which was in line with the reports by Frisvad et al. and Susca et al. [11,12].

Because of their potential mycotoxin production and pathogenicity to humans and animals, strains of A.niger have been considered as risk group 2 biological agents by the German Federal Institute for Occupational Safety and Health [13]. Our findings show that strains of A.niger intended used in the Chinese food industry are indeed capable of producing OTA, and their toxin-producing abilities are highly related to their industrial applications and their culture conditions such as time and substrate, as well as being strain-specific. Because strains of A.niger are one of the most important industrial fungi for food additive production in China, it is very important to evaluate their toxin-producing ability before industrial use.

\section{Materials and Methods}

\subsection{Chemicals and Reagents}

A standard of OTA with purities higher than $98 \%$ was purchased from Romer Labs (IFA-Tulln, Austria). All the organic solvents such as acetic acid, methanol, and acetonitrile used in this study in the HPLC grade were obtained from Fisher Scientific (Fair Lawn, NJ, USA). Other reagents such as $\mathrm{NaCl}, \mathrm{NaHCO}_{3}$, and tween 20 were of analytical grade and obtained from Sigma-Aldrich (St. Louis, MO, USA). An OchraTest immunoaffinity column was purchased from VICAM (Clover Technology Group, Beijing, China). Pure water was prepared in our lab by a Millipore Milli-Q system (Millipore, Bedford, MA, USA) with a conductivity higher than $18.2 \mathrm{M} \Omega$ at $25^{\circ} \mathrm{C}$.

\subsection{Strains of Fungi}

There were thirty strains of A.niger used in this study. From the point of view of the industrial application, the twenty-seven strains of A.niger with intended uses in the Chinese food industry were divided into four groups, including the thirteen strains used for saccharifying enzyme production, the six strains used for organic acid production, the seven strains used for tannase production, and one strain used as for $\beta$-galactosidase production. In addition, there were three strains where one was used for research and teaching in classification, another used for antifungal activity determination, and one strain isolated from corn. Detailed information about the thirty strains of A.niger is shown in Table 3. 
Table 3. Information about the strains of A.niger used in this study.

\begin{tabular}{|c|c|c|c|c|}
\hline Potential Application & Strain No. & Isolated Substrate & $\begin{array}{l}\text { Optimum Culture } \\
\text { Temperature }\left({ }^{\circ} \mathrm{C}\right)\end{array}$ & $\begin{array}{c}\text { Obtained } \\
\text { Center/Place }^{2} \\
\end{array}$ \\
\hline \multirow{13}{*}{$\begin{array}{l}\text { Saccharifying enzyme } \\
\text { production }(n=13)\end{array}$} & SN-01 & $\mathrm{nr}^{1}$ & $25-28$ & ACCC \\
\hline & $\mathrm{SN}-02$ & $\begin{array}{l}\text { Mold culture used for } \\
\text { wine fermentation }\end{array}$ & $25-28$ & ACCC \\
\hline & SN-03 & $\mathrm{nr}$ & $25-28$ & ACCC \\
\hline & SN-04 & $\mathrm{nr}$ & $25-28$ & ACCC \\
\hline & SN-05 & $\mathrm{nr}$ & $30-32$ & ACCC \\
\hline & SN-06 & $\mathrm{nr}$ & $30-32$ & ACCC \\
\hline & SN-07 & $\mathrm{nr}$ & $25-28$ & CGMCC \\
\hline & SN-08 & $\mathrm{nr}$ & $25-28$ & CGMCC \\
\hline & SN-09 & $\mathrm{nr}$ & $25-28$ & CGMCC \\
\hline & SN-10 & $\mathrm{nr}$ & $25-28$ & CGMCC \\
\hline & SN-11 & $\mathrm{nr}$ & $25-28$ & CGMCC \\
\hline & $\mathrm{SN}-12$ & $\mathrm{nr}$ & $25-28$ & CGMCC \\
\hline & $\mathrm{SN}-13$ & $\mathrm{nr}$ & $25-28$ & CGMCC \\
\hline \multirow{6}{*}{$\begin{array}{l}\text { Organic acid production } \\
\qquad(n=6)\end{array}$} & OA-01 & $\mathrm{nr}$ & $25-28$ & CGMCC \\
\hline & OA-02 & $\mathrm{nr}$ & $25-28$ & CGMCC \\
\hline & OA-03 & $\mathrm{nr}$ & $29-31$ & ACCC \\
\hline & OA-04 & $\mathrm{nr}$ & $25-28$ & CGMCC \\
\hline & OA-05 & $\mathrm{nr}$ & $25-28$ & CGMCC \\
\hline & OA-06 & $\mathrm{nr}$ & $25-28$ & ACCC \\
\hline \multirow{7}{*}{$\begin{array}{l}\text { Tannase production } \\
\qquad(n=7)\end{array}$} & TA-01 & $\mathrm{nr}$ & $25-28$ & CGMCC \\
\hline & TA-02 & Eucalyptus leaves & $25-28$ & CGMCC \\
\hline & TA-03 & Rotten soil & $25-28$ & CGMCC \\
\hline & TA-04 & $\mathrm{nr}$ & $25-28$ & CGMCC \\
\hline & TA-05 & Rotten wood & $25-28$ & CGMCC \\
\hline & TA-06 & Rotten wood & $25-28$ & CGMCC \\
\hline & TA-07 & Rotten wood & $25-28$ & CGMCC \\
\hline $\begin{array}{l}\beta \text {-galactosidase production } \\
(n=1)\end{array}$ & GA-01 & Moldy bagasse & $25-28$ & CGMCC \\
\hline Research and Teaching & ACCC 30557 & Cloth & 24 & ACCC \\
\hline $\begin{array}{l}\text { Used as the reference strain } \\
\text { for medium control, method } \\
\text { validation, etc. }\end{array}$ & ATCC 16404 & nr & $25-28$ & ATCC \\
\hline No practical application & SI-01 & Corn & $25-28$ & Our lab \\
\hline
\end{tabular}

\subsection{OTA Production}

For the activation and sporulation of the strains of A.niger, the studied thirty strains were inoculated on the Czapek agar slants, respectively, and incubated at $28 \pm 1{ }^{\circ} \mathrm{C}$ for one week. The spore suspension of A.niger was made by using sterilized distilled water, scraping the spores, and mixing thoroughly with the inoculating hook. Each flask containing $100 \mathrm{~g}$ polished rice or corn or wheat bran was autoclaved twice on successive days at $121^{\circ} \mathrm{C}$ for $20 \mathrm{~min}$. Before inoculation, the autoclaved flask containing rice or corn or wheat bran was adjusted to $20 \%$ (30\% for wheat bran) relative moisture by adding sterilized distilled water, and then it was inoculated with $5 \mathrm{~mL}$ of one week old A.niger spore suspension or $5 \mathrm{~mL}$ sterilized distilled water used as a control in two parallel, respectively. After inoculation, all of them were incubated in the dark at $28 \pm 1{ }^{\circ} \mathrm{C}$ for 4 weeks. For the time profile study, we collected $10 \mathrm{~g}$ of fermented cultures on day 7, day 14, day 21, and day 28 and detected the concentrations of OTA. All fermented cultures were left standing for the first three days after inoculation and shaken two times per day to reduce clumping. Three substrates—corn, rice, and wheat bran-without OTA or with OTA lower than the limit of detection were used as control. 


\subsection{OTA Extraction}

The OTA extraction was performed based on the Chinese food safety standard GB/T 23502-2009: determination of ochratoxin A in food high-performance liquid chromatographic method with OchraTest immunoaffinity column clean-up with some modifications [23]. Briefly, $5.0 \mathrm{~g}$ of fermented cultures were homogenized completely by adding $20 \mathrm{~mL}$ of methanol-water $(80: 20, v / v)$, and extracted at $200 \mathrm{rpm}$ from an orbital shaker (Eyela Inc., Tokyo, Japan) for $60 \mathrm{~min}$, and the mixture was then centrifuged at 10,000 rpm for $15 \mathrm{~min}$ (Beckman Coulter, Brea, CA, USA). Ten mL supernatant was diluted with $40 \mathrm{~mL}$ phosphate buffer $(8.0 \mathrm{~g} \mathrm{NaCl}, 1.2 \mathrm{~g}$ sodium hydrogen phosphate, $0.2 \mathrm{~g}$ potassium dihydrogen phosphate, and $0.2 \mathrm{~g}$ potassium chloride per $1 \mathrm{~L}, \mathrm{pH} 7.0$ ). All the diluted extracts were pushed through the immunoaffinity column, followed by washing with $10 \mathrm{~mL}$ mycotoxin cleaning buffer $\left(2.5 \mathrm{~g} \mathrm{NaCl}, 5.0 \mathrm{~g} \mathrm{NaHCO}_{3}\right.$, and $0.1 \mathrm{~mL}$ Tween 20 per $\left.1 \mathrm{~L}\right)$ and $10 \mathrm{~mL}$ water. Finally, $1.5 \mathrm{~mL}$ methanol was used to elute the column, and the purified product was used for HPLC analysis.

\subsection{HPLC Conditions}

Detection and quantification of OTA were performed on an Agilent HPLC 1200 system with a fluorescence detector (Santa Clara, CA, United States) and an Agilent ZORBAX SB-C 18 column $(150 \mathrm{~mm} \times 4.6 \mathrm{~mm}$ i.d., $5 \mu \mathrm{m}$ particle size $)$ at a temperature of $40^{\circ} \mathrm{C}$. It was detected in the isometric elution with the mobile phase and included acetonitrile as solvent $\mathrm{A}$ and $2.5 \%$ formic acid in water as solvent $\mathrm{B}(50: 50, v / v)$ and a flow rate of $0.8 \mathrm{~mL} / \mathrm{min}$. In addition, the detecting excitation wavelength and the emission wavelength for the OTA detection were $333 \mathrm{~nm}$ and $477 \mathrm{~nm}$, respectively.

\subsection{HPLC Method Validation}

Mean recoveries for the three substrates were detected with the three parallel analyses of OTA-free corn, rice, and wheat bran samples spiked with $1.0 \mu \mathrm{g} / \mathrm{kg}$ to $10.0 \mu \mathrm{g} / \mathrm{kg}$, and they were in the range between $79.10 \pm 10.31 \%$ and $102.60 \pm 9.41 \%$ for corn, $80.80 \pm 9.12 \%$ and $95.78 \pm 6.71 \%$ for rice, and $83.13 \pm 7.45 \%$ and $110.45 \pm 6.45 \%$ for wheat bran, respectively. Method repeatability and reproducibility were also determined with the toxin-free samples by spiking OTA into the OTA-free substrates according to the requirements of European Union Decision 2002/657/EEC [24]. All these data shown that the relative standard deviations for OTA detection in the above three natural substrates ranged from $4.31 \%$ to $6.74 \%$ for intra-day and $5.89 \%$ to $10.65 \%$ for inter-day, respectively. The limit of detection and the limit of quantification for OTA detection in the studied three substrates were all $0.03 \mu \mathrm{g} / \mathrm{kg}$ and $0.1 \mu \mathrm{g} / \mathrm{kg}$.

\subsection{Data Analysis}

All the concentrations of OTA at different time intervals on different substrates were obtained using the software OpenLAB CDS A.02.01 (Santa Clara, CA, USA). Parameters such as the frequency, the mean, and the range of OTA for strains of A.niger used in this study were obtained by applying the SPSS statistical package (version 20.0, IBM, Amund, NY, USA). The analysis of variance (ANOVA) was employed for statistical analysis by comparing the concentrations of OTA on different substrates and time intervals.

Author Contributions: X.H. and H.J. contributed equally to experiment performance, data analysis, and manuscript writing. F.L. designed the experiments, contributed to the manuscript writing, and decided to publish the results.

Funding: This research received no external funding.

Acknowledgments: This work was financially supported by National Natural Science Foundation (Grant Number: 31301489 and Grant Number: 81072307), Beijing Natural Science Foundation (Grant Number: 7163235), and China Food Safety Talent Competency Development Initiative (CFSA 523 Program).

Conflicts of Interest: The authors declare no conflict of interest. The funding sponsors had no role in the design of the study; in the collection, analyses, or interpretation of the data; in the manuscript writing, and the decision to publish the results. 


\section{References}

1. Van der Merwe, K.J.; Steyn, P.S.; Fourie, L.; Scott, D.B.; Theron, J.J. Ochratoxin A, a toxic metabolite produced by Aspergillus ochraceus Wilh. Nature 1965, 205, 1112-1113. [CrossRef] [PubMed]

2. Varga, J.; Rigó, K.; Téren, J.; Mesterházy, Á. Recent advances in ochratoxin research I. Production, detection and occurrence of ochratoxins. Cereal Res. Commun. 2001, 29, 85-92.

3. Smith, J.E.; Moss, M.O. Mycotoxins, formation, analysis and significance. Food Microbiol. 1985, 2, 291.

4. International Agency for Research on Cancer (IARC). Some naturally occurring substances: Food items and constituents, heterocyclic aromatic amines and mycotoxins. IARC Monogr. Eval. Carcinog. Risks Hum. WHO/IARC Lyons 1993, 56, 1-599.

5. Pel, H.J.; de Winde, J.H.; Archer, D.B.; Dyer, P.S.; Hofmann, G.; Schaap, P.J.; Turner, G.; de Vries, R.P.; Albang, R.; Albermann, K.; et al. Genome sequencing and analysis of the versatile cell factory Aspergillus niger. Nat. Biotechnol. 2007, 25, 221-231. [CrossRef]

6. Nielsen, K.F.; Mogensen, J.M.; Johansen, M.; Larsen, T.O.; Frisvad, J.C. Review of secondary metabolites and mycotoxins from the Aspergillus niger group. Anal. Bioanal. Chem. 2009, 395, 1225-1242. [CrossRef] [PubMed]

7. Accensi, F.; Abarca, M.L.; Cabañes, F.J. Occurrence of Aspergillus species in mixed feeds and component raw materials and their ability to produce ochratoxin A. Food Microbiol. 2004, 21, 623-627. [CrossRef]

8. Abarca, M.L.; Bragulat, M.R.; Castellá, G.; Cabañes, F.J. Ochratoxin A production by strains of Aspergillus niger var.niger. Appl. Environ. Microbiol. 1994, 60, 2650-2652.

9. Marino, A.; Fiorentino, C.; Spataro, F.; Nostro, A. Effect of temperature on production of Ochratoxin A by Aspergillus niger in orange juice. J. Toxins 2014, 2014, 1-5. [CrossRef]

10. Astoreca, A.L.; Barberis, C.L.; Magnoli, C.E.; Dalcero, A. Growth and ochratoxin A production by Aspergillus niger group strains in coffee beans in relation to environmental factors. World Mycotoxin J. 2010, 3, 59-65. [CrossRef]

11. Frisvad, J.C.; Larsen, T.O.; Thrane, U.; Meijer, M.; Varga, J.; Samson, R.A.; Nielsen, K.F. Fumonisin and ochratoxin production in industrial Aspergillus niger strains. PLoS ONE 2011, 6, e23496. [CrossRef] [PubMed]

12. Susca, A.; Proctor, R.H.; Morelli, M.; Haidukowski, M.; Gallo, A.; Logrieco, A.F.; Moretti, A. Variation in fumonisin and ochratoxin production associated with differences in biosynthetic gene content in Aspergillus niger and A. welwitschiae isolates from multiple crop and geographic origins. Front. Microbiol. 2016, 7, 1412. [CrossRef] [PubMed]

13. Frisvad, J.C.; Lars, L.H.M.; Larsen, T.O.; Kumar, R.; Arnau, J. Safety of the fungal workhorses of industrial biotechnology: Update on the mycotoxin and secondary metabolite potential of Aspergillus niger, Aspergillus oryzae, and Trichoderma reesei. Appl. Environ. Microbiol. 2018, 102, 9481-9515. [CrossRef] [PubMed]

14. Han, X.M.; Jiang, H.R.; Xu, J.; Zhang, J.; Li, F.Q. Dynamic fumonisin $\mathrm{B}_{2}$ production by Aspergillus niger intended used in food industry in China. Toxins 2017, 9, 217. [CrossRef] [PubMed]

15. Romero, S.M.; Comeria, R.M.; Larumbe, G.; Ritieni, A.; Vaamonde, G.; Fernández, P.V. Toxigenic fungi isolated from dried vine fruits in Argentina. Int. J. Food Microbiol. 2005, 104, 43-49. [CrossRef]

16. Magnoli, C.; Violante, M.; Combina, M.; Palacio, G.; Dalcero, A. Mycoflora and ochratoxin-producing strains of Aspergillus section Nigri in wine grapes in Argentina. Lett. Appl. Microbiol. 2010, 37, 179-184. [CrossRef]

17. Susca, A.; Proctor, R.H.; Butchko, R.A.; Haidukowski, M.; Stea, G.; Logrieco, A.; Moretti, A. Variation in the fumonisin biosynthetic gene cluster in fumonisin-producing and nonproducing black Aspergilli. Fungal Genet. Biol. 2014, 73, 39-52. [CrossRef]

18. Ferracin, L.M.; Fier, C.B.; Vieira, M.L.C.; Viorello, C.B.M.; Varani Ade, M.; Rossi, M.M.; Santos, M.M.; Taniwaki, M.H.; Lamanaka, B.T.; Fungaro, M.H.P. Strain-specific polyketide synthase genes of Aspergillus niger. Int. J. Food Microbiol. 2012, 155, 137-145. [CrossRef]

19. Zhang, J.; Zhu, L.Y.; Chen, H.Y.; Li, M.; Zhu, X.J.; Gao, Q.; Wang, D.P.; Zhang, Y. A polyketide synthase encoded by the gene An15g07920 is involved in the biosynthesis of ochratoxin A in Aspergillus niger. J. Agric. Food Chem. 2016, 64, 9680-9688. [CrossRef]

20. Castellá, G.; Alborch, L.; Bragulat, M.R.; Cabañes, F.J. Real time quantitative expression study of a polyketide synthase gene related to ochratoxin a biosynthesis in Aspergillus niger. Food Control 2015, 53, 147-150. [CrossRef] 
21. von Hertwig, A.M.; Ana, A.S.S.; Sartori, D.; da Silva, J.J.; Nascimento, M.S.; Iamanaka, B.T.; Fungaro, M.H.P.; Taniwaki, M.H. Real-time PCR-based method for rapid detection of Aspergillus niger and Aspergillus welwitschiae isolated from coffee. J. Microbiol. Methods 2018, 148, 87-92. [CrossRef]

22. Jessica, G.S.; Marta, G.D.; María, T.G.J.; Covadonga, V.; Belén, P. Description of an orthologous cluster of ochratoxin A biosynthetic genes in Aspergillus and Penicillium species. A comparative analysis. Int. J. Food Microbiol. 2018, 268, 35-43.

23. Standardization Administration of the People's Republic of China. Determination of Ochratoxin a in Food-High Performance Liquid Chromatographic Method With Immunoaffinity Column Clean-Up. GB 5009.96-2016; SAC: Beijing, China, 2017. Available online: http:/ / down.foodmate.net/standard/sort/3/50478.html (accessed on 23 June 2017).

24. European Union Decision 2002/657/EC. Commission Decision of 12 August 2002 Implementing Council Directive 96/23/EC concerning the performance of analytical methods and the interpretation of results. Off. J. Eur. Common. 2001, L221, 8-36.

(C) 2019 by the authors. Licensee MDPI, Basel, Switzerland. This article is an open access article distributed under the terms and conditions of the Creative Commons Attribution (CC BY) license (http:/ / creativecommons.org/licenses/by/4.0/). 